\title{
Study on the Comprehensive Financial Performance and Provincial Difference of Travel Agency Industry of China-Based on Catastrophe Progression Theory and Entropy Method
}

\author{
Yunxin Fu, Qiong Li, Haiyan Feng \\ School of Management, Jinan University, Guangzhou, China \\ Email: 1899044595@163.com, tfuyx@jnu.edu.cn
}

Received 8 January 2015; accepted 25 February 2015; published 28 February 2015

Copyright (C) 2015 by authors and Scientific Research Publishing Inc.

This work is licensed under the Creative Commons Attribution International License (CC BY). http://creativecommons.org/licenses/by/4.0/

\section{(c) (j) Open Access}

\begin{abstract}
The performance of travel agencies has always been the focus and its quantitative evaluation is also an important study field. From financial view, the catastrophe progression method and the entropy method are used to build a evaluation indicator system of comprehensive financial performance for travel agency industry applying statistical data of the major financial indicator of travel agency from 2005 to 2012, and then empirical research on comprehensive financial performance of travel agencies from 30 different provinces, except Hong Kong, Macao and Taiwan regions and Tibet is made. The result indicates that when the financial performance of travel agency is measured, profitability is the most important indicator, followed by development, solvency and asset management capabilities; through empirical research, the financial performance of travel agencies from 30 different provinces is evaluated and ranked. Finally the reasons are discussed.
\end{abstract}

\section{Keywords}

Travel Agency Industry, Comprehensive Financial Performance, Catastrophe Progression Method, Entropy Method

\section{Introduction}

Travel agency is a bond to link all related factors of tourism and plays a very important role in enhancing tour- 
ism development. The travel agency industry has continuously expanded since reform and openness as quantity and scale have been grown. While the performance of travel agency industry is disappointing, profit margin has been less than $2 \%$ for 14 years [1], leading to a name of "thin profit industry". The bad performance of travel agency industry attaches concentration in academic field. The main cause of low performance is property rights [2] [3]; competitive efficiency is the factor to affect performance of travel agency pointed by Yang Hui [4], and he also indicated that the environment of effective market competition formed through reforming system is an essential way which can improve the performance of travel agency. Yang Danhui, Dong Hongxia and Fan Yuefeng respectively researched the relationship between performance of travel agency market and industry concentration rate based on SCP model, and concluded that the lower the industry concentration rate is, the worse the performance of travel agency is. It is very common that travel agency has a low profit and heated competition, and how to effectively value the performance of travel agency should be paid urgent attention [5]-[7]. Some scholars have made effort to explore the evaluation on growth of over-margin profit [8], a system of performance evaluation of travel agency in China based on entropy method [9]; Yang Yan did empirical study on outbound travel of 16 travel agencies in Nanjing via linear weighting method and DuPont analysis [10].

Although research on performance of travel agency has made some progress, quantitative evaluation and empirical study on it are relatively lacking, and moreover existing methods to measure the performance of travel agency are limited, which have difficulty to collect data, and can be affected subjectively, so the methods can't be applied widely in the whole industry. Regional performance of travel agency can't be judged by a special financial indicator, and integrated estimation needs to create a reasonable evaluation system. With incessant integration of domestic accounting system, financial statistics can reflect synthetically operating situation, and are objective, successive and accessible; it is a feasible way to weigh market performance and operate future. The target is to establish an evaluation indicator system of comprehensive financial performance for travel agency industry which is universally applicable, calculating financial performance of provincial travel agency and analyzing the difference of comprehensive financial performance from 30 different provinces.

\section{Research Methodology}

\subsection{Catastrophe Progression Method}

Catastrophe progression method is derived from catastrophe model of catastrophe theory, which is a multi-level factorization of evaluation target, catastrophe fuzzy subordinate function is obtained through combination catastrophe method and fuzzy mathematic, comprehensive quantitative computation is done via formula, finally they are unified into one parameter to get a general subordinate function, sorting the indicator of evaluation target. Although weight of indicator is not applied in Catastrophe progression method, it contains relative importance of each indicator which has attribution to easy calculation and widely application, so that it properly avoids subjectivity, unreason and false science, it has been applied to research on competition of tourism industry, market performance and growth of listed tourism company [11]-[13].

\subsection{Entropy Method}

Entropy is one of reference variables representing state of motion substance in thermodynamics, indicating the degree of chaos during microscopic thermal motion. Entropy has varied meanings in different field and is a measurement to system degree of disorder. If the smaller information entropy of an index is, the lower degree of disorder is, otherwise, the bigger information entropy is, the higher degree of disorder is, which pay less role and lower weigh. Entropy is an objective and precise way, which avoids subjective judge in the process of distributing indicator weight and guarantees the consistence between order of index and relative degree of importance. Entropy is widely applied to confirm the indicators weight [14]-[16].

\subsection{The Evaluation Index System of Comprehensive Financial Performance for Travel Agency Industry-Based on Catastrophe Progression Method and Entropy Method}

\subsubsection{The Selection of Evaluation Index of Comprehensive Financial Performance for Travel Agency}

To create evaluation index system of comprehensive financial performance for travel agency, author cites current financial indicator included in statistical yearbook of tourism financial information. Because statistic data of 
stock turnover rate is missing, intangibility of product or service offered by travel agency decides that the stock only meets need to routine management and operation, which has no direct relationship with major business and the quantity and value ratio of stock is relatively small [9], the index of stock turnover rate should be removed, The evaluation indicator system of comprehensive financial performance of travel agency is showed as Table 1.

\subsubsection{Calculating Comprehensive Financial Performance for Travel Agency Industry}

According to the catastrophe progression method, evaluation target should be divided into some level indicators, each secondary indicator attached to level indicator is ordered from left to right on degree of importance, when same layer indicators are appraised, degree of importance is ranked relying on its weight. Entropy method counts weight of each indicator to avoid ordering subjectively, and ranks in descending order. This result sorts the important degree of the secondary indicators based on the entropy method, and then calculates the indicators of comprehensive financial performance in the light of catastrophe progression method.

\section{Empirical Research}

\subsection{Data Resource}

Statistical data of major financial indicator of travel agency industry of China ranging 2005 from 2012 and statistical data of major financial index of travel agency of 30 different regions is used, except Hong Kong, Macao and Taiwan regions and Tibet, for which statistical data of these is missing. All statistical data come from Yearbook of Chinese Tourism Financial Information.

\subsection{Calculation of Indicators Weights Based on Entropy}

According to Yearbook of Chinese Tourism Financial Information of China from 2005 to 2012, author arranged statistical data (exclude stock turnover rate) of major financial indicators of travel agency industry of 30 different provinces, and founded matrix of original statistical data, calculated entropy and indicator weights of comprehensive financial performance of travel agency industry on the basis of step to valuation of entropy method showed in Table 2.

Conclusion made from important degree of level indicators is ranked in descending sequent as profitability, asset operating capabilities, solvency, development ability, in which important degree of secondary indicators

Table 1. The evaluation indicators system of comprehensive financial performance for travel agency industry.

\begin{tabular}{|c|c|c|}
\hline Evaluation target A & Level indicators B & Secondary indicators C \\
\hline \multirow{14}{*}{$\begin{array}{l}\text { Comprehensive financial } \\
\text { performance (A) }\end{array}$} & \multirow{4}{*}{ Profitability $\left(\mathrm{B}_{1}\right)$} & Return on assets $\left(\mathrm{C}_{1}\right)$ \\
\hline & & Return on total asset $\left(\mathrm{C}_{2}\right)$ \\
\hline & & Operating margin $\left(\mathrm{C}_{3}\right)$ \\
\hline & & Cost margin $\left(\mathrm{C}_{4}\right)$ \\
\hline & \multirow{3}{*}{ Asset operating capabilities $\left(\mathrm{B}_{2}\right)$} & Total asset turnover $\left(\mathrm{C}_{5}\right)$ \\
\hline & & Current asset turnover $\left(\mathrm{C}_{6}\right)$ \\
\hline & & Accounts receivable turnover $\left(\mathrm{C}_{7}\right)$ \\
\hline & \multirow{4}{*}{ Solvency $\left(B_{3}\right)$} & Asset-liability ratio $\left(\mathrm{C}_{8}\right)$ \\
\hline & & liquidity ratio $\left(\mathrm{C}_{9}\right)$ \\
\hline & & Acid-test ratio $\left(\mathrm{C}_{10}\right)$ \\
\hline & & Long-term assets for rate $\left(\mathrm{C}_{11}\right)$ \\
\hline & \multirow{3}{*}{ Development ability $\left(\mathrm{B}_{4}\right)$} & sales growth rate $\left(\mathrm{C}_{12}\right)$ \\
\hline & & Capital cumulative rate $\left(\mathrm{C}_{13}\right)$ \\
\hline & & total assets growth rate $\left(\mathrm{C}_{14}\right)$ \\
\hline
\end{tabular}


Table 2. Indicator weights of comprehensive financial performance of travel agency based on entropy.

\begin{tabular}{|c|c|c|c|c|c|}
\hline Level indicators & Secondary indicators & Entropy & $\begin{array}{l}\text { Coefficient of } \\
\text { variance }\end{array}$ & $\begin{array}{l}\text { Weights of secondary } \\
\text { indicators }\end{array}$ & $\begin{array}{l}\text { Weights of level } \\
\text { indicators }\end{array}$ \\
\hline \multirow{4}{*}{ Profitability } & Return on assets (\%) & 0.9447 & 0.0553 & 0.0510 & \multirow{4}{*}{0.3277} \\
\hline & Return on total asset (\%) & 0.9484 & 0.0516 & 0.0476 & \\
\hline & Operating margin (\%) & 0.9386 & 0.0614 & 0.0566 & \\
\hline & Cost margins (\%) & 0.8129 & 0.1871 & 0.1725 & \\
\hline \multirow{3}{*}{$\begin{array}{l}\text { Asset operating } \\
\text { capabilities }\end{array}$} & Total asset turnover (\%) & 0.9282 & 0.0718 & 0.0662 & \multirow{3}{*}{0.1385} \\
\hline & Current asset turnover (\%) & 0.9714 & 0.0286 & 0.0263 & \\
\hline & Accounts receivable turnover (\%) & 0.9502 & 0.0498 & 0.0459 & \\
\hline \multirow{4}{*}{ Solvency } & Asset-liability ratio (\%) & 0.9351 & 0.0649 & 0.0599 & \multirow{4}{*}{0.2562} \\
\hline & Liquidity ratio (\%) & 0.9202 & 0.0798 & 0.0736 & \\
\hline & Acid-test ratio (\%) & 0.9266 & 0.0734 & 0.0677 & \\
\hline & Long-term assets for rat (\%) & 0.9403 & 0.0597 & 0.0551 & \\
\hline \multirow{3}{*}{$\begin{array}{l}\text { Development } \\
\text { ability }\end{array}$} & Sales growth rate (\%) & 0.8283 & 0.1717 & 0.1583 & \multirow{3}{*}{0.2776} \\
\hline & Capital cumulative rate (\%) & 0.9389 & 0.0611 & 0.0564 & \\
\hline & Total assets growth rate (\%) & 0.9318 & 0.0682 & 0.0629 & \\
\hline
\end{tabular}

reflects profitability ranging as cost margins, operating margin, return on assets, return on total asset; While development ability is reflected by important degree of secondary indicators sorting as sales growth rate, total assets growth rate, capital cumulative rate; Solvency is reflected by important degree of secondary indicators sorting as liquidity ratio, acid-test ratio, asset-liability ratio, long-term assets for rate; asset operating capabilities is reflected by important degree of secondary indicators sorting as total asset turnover ratio, accounts receivable turnover ratio, current asset turnover ratio.

\subsection{Calculating Comprehensive Financial Performance for Travel Agency Industry Based on Catastrophe Progression Method}

\subsubsection{Calculating Procedure of Catastrophe Progression Method}

After confirming indicators system of comprehensive financial performance for travel agency industry and sequence of relatively important degree of each layer indicators, according to requirement of catastrophe progression method, author tries to handle the original data to standardization, and then calculate based on mutation system normalized formula.

A case study of Beijing travel agency industry, author calculates indicators from all layers

1) Butterfly mutation system model is consist of $\mathrm{C}_{1}, \mathrm{C}_{2}, \mathrm{C}_{3}, \mathrm{C}_{4}$ of secondary indicators, formula is listed as $\mathrm{XB}_{1}=\left(\mathrm{XC}_{1} 1 / 2+\mathrm{XC}_{2} 1 / 3+\mathrm{XC}_{3} 1 / 4+\mathrm{XC}_{4} 1 / 5\right) / 4=0.8942$ in accordance to complementary principle; $\mathrm{C}_{5}, \mathrm{C}_{6}, \mathrm{C}_{7}$ of secondary indicators compose dovetail mutation system model, reaching formula $\mathrm{XB}_{2}=\left(\mathrm{XC}_{5} 1 / 2+\mathrm{XC}_{6} 1 / 3+\right.$ $\left.\mathrm{XC}_{7} 1 / 4\right) / 3=0.7285$ based on complementary principle; $\mathrm{C}_{8}, \mathrm{C}_{9}, \mathrm{C}_{10}, \mathrm{C}_{11}$ of secondary indicators constitute butterfly mutation system model, and formula is listed as $\mathrm{XB}_{3}=\left(\mathrm{XC}_{8} 1 / 2+\mathrm{XC}_{9} 1 / 3+\mathrm{XC}_{10} 1 / 4+\mathrm{XC}_{11} 1 / 5\right) / 4=$ 0.8069 based on complementary principle; $\mathrm{C}_{12}, \mathrm{C}_{13}, \mathrm{C}_{14}$ of secondary indicators make up dovetail mutation system model, get a formula of $\mathrm{XB}_{4}=\left(\mathrm{XC}_{12} 1 / 2+\mathrm{XC}_{13} 1 / 3+\mathrm{XC}_{14} 1 / 4\right) / 3=0.5295$ according to complementary principle.

2) $B_{1}, B_{2}, B_{3}, B_{4}$ of level indicators compose butterfly mutation system model, formula is listed as $X A=$ $\left(\mathrm{XB}_{1} 1 / 2+\mathrm{XB}_{2} 1 / 3+\mathrm{XB}_{3} 1 / 4+\mathrm{XB}_{4} 1 / 5\right) / 4=0.9184$ in accordance to complementary principle, so level indicators evaluation result data of comprehensive financial performance travel agency industry of Beijing is calculated, Similarly, indicators evaluation result data of comprehensive financial performance travel agency industry of other cities can be obtained. 
3.3.2. The Ranks of Comprehensive Financial Performance of Travel Agency from 30 Provinces According previous method and step, calculates calculation weight of comprehensive financial performance of travel agency of 30 provinces and level indicator then ranks it as Table 3.

\section{Discussion}

Comprehensive financial performance of travel agency industry is the final achievement, which is affected by many factors. The factors which cause difference to comprehensive financial performance of travel agency industry of different provinces are divided into two facets: uncontrollable factors and controllable factors. The uncontrollable factors mainly include distinction of economical development and resource endowment, and the controllable factors contain management ability of travel agency and market competitive degree.

Table 3. The ranks of comprehensive financial performance of travel agency of each province.

\begin{tabular}{|c|c|c|c|c|c|c|c|c|c|c|}
\hline Province & Profitability & Rank & $\begin{array}{c}\text { Asset } \\
\text { operating } \\
\text { capabilities }\end{array}$ & Rank & Solvency & Rank & $\begin{array}{c}\text { Development } \\
\text { ability }\end{array}$ & Rank & $\begin{array}{l}\text { Comprehensive } \\
\text { financial } \\
\text { performance }\end{array}$ & Rank \\
\hline Hunan & 0.8681 & 5 & 1.0000 & 1 & 0.8302 & 6 & 0.9497 & 2 & 0.9673 & 1 \\
\hline Chongqing & 0.7637 & 19 & 0.8485 & 2 & 0.8110 & 15 & 0.9645 & 1 & 0.9446 & 2 \\
\hline Shanghai & 0.9294 & 2 & 0.6247 & 20 & 0.8101 & 16 & 0.7900 & 5 & 0.9369 & 3 \\
\hline Jiangsu & 0.8517 & 6 & 0.7422 & 5 & 0.8084 & 18 & 0.7566 & 9 & 0.9311 & 4 \\
\hline Zhejiang & 0.8336 & 10 & 0.7311 & 8 & 0.8063 & 21 & 0.7845 & 6 & 0.9305 & 5 \\
\hline Fujian & 0.7986 & 13 & 0.7397 & 6 & 0.8114 & 14 & 0.7816 & 7 & 0.9263 & 6 \\
\hline Inner Mongolia & 0.8243 & 11 & 0.5613 & 22 & 0.8376 & 4 & 0.7948 & 4 & 0.9205 & 7 \\
\hline Guangdong & 0.8486 & 7 & 0.6760 & 16 & 0.7996 & 23 & 0.6961 & 18 & 0.9194 & 8 \\
\hline Beijing & 0.8942 & 3 & 0.5295 & 24 & 0.8069 & 20 & 0.7285 & 15 & 0.9184 & 9 \\
\hline Hubei & 0.7843 & 15 & 0.7060 & 12 & 0.8077 & 19 & 0.7341 & 13 & 0.9171 & 10 \\
\hline Sichuan & 0.7529 & 20 & 0.7763 & 4 & 0.7336 & 27 & 0.7728 & 8 & 0.9154 & 11 \\
\hline Jiangxi & 0.7344 & 22 & 0.7315 & 7 & 0.8385 & 3 & 0.7457 & 10 & 0.9150 & 12 \\
\hline Yunnan & 0.7733 & 17 & 0.7100 & 11 & 0.8095 & 17 & 0.6956 & 19 & 0.9119 & 13 \\
\hline Liaoning & 0.7833 & 16 & 0.7869 & 3 & 0.7855 & 25 & 0.6465 & 23 & 0.9111 & 14 \\
\hline Ningxia & 0.8133 & 12 & 0.7276 & 9 & 0.6484 & 28 & 0.7316 & 14 & 0.9096 & 15 \\
\hline Anhui & 0.8408 & 9 & 0.7048 & 13 & 0.6278 & 29 & 0.7063 & 17 & 0.9075 & 16 \\
\hline Shanxi & 0.6829 & 25 & 0.6259 & 19 & 0.9494 & 1 & 0.7374 & 11 & 0.9069 & 17 \\
\hline Shandong & 0.8439 & 8 & 0.7006 & 14 & 0.7924 & 24 & 0.5773 & 28 & 0.9065 & 18 \\
\hline Henan & 0.7862 & 14 & 0.5784 & 21 & 0.8241 & 9 & 0.6379 & 24 & 0.8991 & 19 \\
\hline Hebei & 0.7214 & 23 & 0.6390 & 18 & 0.8230 & 10 & 0.6552 & 22 & 0.8962 & 20 \\
\hline Shanxi & 0.7421 & 21 & 0.5278 & 25 & 0.8316 & 5 & 0.6663 & 21 & 0.8925 & 21 \\
\hline Tianjin & 0.6831 & 24 & 0.6530 & 17 & 0.8117 & 13 & 0.6701 & 20 & 0.8923 & 22 \\
\hline Heilongjiang & 0.8771 & 4 & 0.5347 & 23 & 0.8690 & 2 & 0.4819 & 29 & 0.8921 & 23 \\
\hline Qinghai & 0.9429 & 1 & 0.1573 & 29 & 0.8161 & 12 & 0.8706 & 3 & 0.8918 & 24 \\
\hline Jilin & 0.6791 & 26 & 0.4404 & 28 & 0.8268 & 8 & 0.6022 & 26 & 0.8677 & 25 \\
\hline Guizhou & 0.4577 & 29 & 0.6839 & 15 & 0.8283 & 7 & 0.7275 & 16 & 0.8642 & 26 \\
\hline Guangxi & 0.7680 & 18 & 0.7261 & 10 & 0.8188 & 11 & 0.3164 & 30 & 0.8617 & 27 \\
\hline Hainan & 0.4767 & 28 & 0.5195 & 27 & 0.8027 & 22 & 0.7357 & 12 & 0.8542 & 28 \\
\hline Xinjiang & 0.6737 & 27 & 0.5195 & 26 & 0.4254 & 30 & 0.6256 & 25 & 0.8402 & 29 \\
\hline Gansu & 0.0967 & 30 & 0.0958 & 30 & 0.7668 & 26 & 0.5888 & 27 & 0.6776 & 30 \\
\hline
\end{tabular}




\section{1) Differences in the level of economic development}

Tourism has close relationship to the level of economic development; low level of economic development has significant influence on comprehensive financial performance of travel agency industry of each province. On one hand, people's discretionary income is decided by level of regional economic development, which will directly affect tourism demand and income of travel agency industry; on the other hand, the level of regional economic development depends on fundamental facilities, traffic condition, exploitive extent of tourism attraction, and indirectly affects financial performance of local travel agency. Regions whose comprehensive financial performance o travel agency industry ranks top ten are coastal areas possessing advanced economy or high level of economic development in the Midwest of China, such as Hunan, Hubei, Inner Mongolia.

\section{2) Differences in the resource endowment}

China is so vast in territory that there exist obvious diversity and difference in nature ecological environment, social culture, resource endowment of each province. Differences in the resource endowment determine that tourism resource attraction, total number and days of tourist reception, income of travel agency, different influent on comprehensive financial performance.

\section{3) Management level of travel agency}

Financial performance of local travel agency is related to management level. For example, asset operating capability that is one of level evaluation indicators of comprehensive financial performance for travel agency industry reflects management level, strategy of product, promotion, price can attach impact on income, cost and development potentiality, further, and financial performance of travel agency is affected by them.

\section{4) Market structure of travel agency industry}

According to SCP (market structure—market conduct—market performance) conceptual model [17], market structure of travel agency industry has impact on market conduct and market performance, there may be exist some distinction on quantity and scale of travel agency to different provinces, and displaying divergence of market structure, then affecting market conduct and market performance. Provincial differences of comprehensive financial performance have relationship to different market structure to a certain degree.

There are many collective factors to cause the provincial difference of financial performance; they are not mutually independent but interactive with each other. Only the managers and scholars should try their best find out main cause to financial performance relying on actual condition of each province and analyzing specific details of travel agency, and make some targeted improvement, the comprehensive financial performance of China can be truly enhanced.

\section{Conclusions}

The author creates a evaluation indicator system of comprehensive financial performance for travel agency industry, through analyzing statistical data from tourism financial information yearbook of China, calculates comprehensive financial performance of travel agency industry from 30 different provinces, except Hong Kong, Macao and Taiwan regions and Tibet based on catastrophe progression theory and entropy method and ranks the comprehensive financial performance. Author makes some conclusions as below:

1) Four level indicators weights of travel agency financial performance are evaluated through entropy, and the important degree is ranked descending as profitability, development ability, solvency and asset operating capability, whose result is consistent to indicators sequence ranked as operating performance, when Weng Gangmin was evaluating thoroughly on listed tourism companies [12]. The most important indicator, which is related to the feature of travel agency industry, is operating margin among the secondary indicators.

2) There is apparent regional difference on comprehensive financial performance of China travel agency industry. Hunan is the best while Gansu is the worst; the top ten regions of comprehensive financial performance are Hunan, Chongqing, Shanghai, Jiangsu, Zhenjiang, Fujian, Inner Mongolia, Guangdong, Beijing and Hubei, where economy is relatively advanced. The last ten regions are Tianjin, Heilongjiang, Qinghai, Jilin, Guizhou, Guangxi, Hainan, Xinjiang and Gansu, where economical development is relatively defective.

3) Considering the comprehensive financial performance of travel agency industry from top ten provinces, profitability and development ability, 60 percent regions rank in top 10, and 90 percent provinces rank in top fifteen. While there exists a little bit distinction on asset operating capability, 50 percent provinces rank in top ten, and 60 percent provinces rank in top fifteen. However, solvency is poor, 50 percent provinces rank in last fifteen. If the province has a brilliant comprehensive financial performance of travel agency industry, it has preference to operating depending on capital from debt. 


\section{References}

[1] Zhai, X.K. and Huang, S.M. (2012) Market Performance and Affecting Factors of China Travel Agency Industry. Tourism Economic, 379, 137-140.

[2] Zhang, H. and Wei, X. (2004) Economical Analyses and Relocation to Travel Agency Industry of China. Tourism Tribune, 19, 71-76.

[3] Song, Z.C. and Ma, Y.G. (2005).Think Property Reform and Scale Operation of Travel Agency Industry—Discussion with Zhanghui and Weixiang. Tourism Tribune, 20, 29-32.

[4] Yang, J. (2006) Analyze Further Cause to Performance of Ravel Agency Industry—Discussion with Zhanghui and Song Zhenchun. Tourism Tribune, 21, 74-76.

[5] Yang, D.H. (2004).Empirical Research on Market Structure and Industry Performance of Ravel Agency Industry. Journal of Capital University of Economics and Business, 4, 23-28.

[6] Dong, H.X. (2006) Analyze on Industrial Concentration and Market Performance of Ravel Agency Industry. Shandong Agriculture University, Tai'an.

[7] Fan, Y.F. (2009) Analyze on Affecting Factors to Market Performance of Travel Agency Industry-Based on Modified SCP Model. Journal of the Yinchuan Municipal Party College of C.P.C., 11, 88-90.

[8] Zhang, X.M. and He, Y. (2003) Exploitation on the Method of Performance Evaluation of Domestic Travel Agency Industry. Journal of Northwest University, 33, 72-76.

[9] Shen, F.P. and Ma, Y.F. (2008) Research on Evaluation Indicators of Financial Performance of Domestic Travel Agency Industry. Economics and Management, 22, 81-84.

[10] Yang, Y. (2011) Research on Financial Performance Evaluation of Domestic Travel Agency Industry Based on Linear Weighting Method and DuPont Analysis-A Case Study of Outbound Travel Agency of Nanjing. Nanjing Normal University, Nanjing.

[11] Weng, G.M. and Ru, C. (2009) Research on Competition of Tourism Industry Based on Catastrophe Progression Theory-A Case Study of Five Provinces from Northwest. Soft Science, 23, 57-61.

[12] Weng, G.M. and Ru, C. (2010) Comprehensive Assessment on Operation Performance of Listed Tourism Companies Based on Catastrophe Progression Theory. Statistics and Decision, 309, 56-59.

[13] Zhang, C.H. and Zhang, H. (2010) Research on Growth Evaluation of Domestic Listed Tourism Companies Based on Catastrophe Progression Theory. Tourism Tribune, 25, 19-27.

[14] Yang, F.W. and Li, X. Application of Financial Indicators Weight of Entropy Method of Peanuts. Communication of Finance and Accounting, 5, 54-55.

[15] Meng, F.S. and Li, M.Y. (2012) Research on Affecting Factors to Energy Consumption—Based on Catastrophe Progression Theory and Improved Entropy Method. Journal of Systems Engineering, 224, 10-15.

[16] Chen, H. (2012) Comprehensive Assessment on Profitability of Pharmaceutical Company Based on Entropy Method-Case Study of Eight Pharmaceutical Companies. Journal of Economic Trade Update, 244, 94.

[17] Zhang, A.M. and Li, Y.W. (2007) Management Measure of Travel Agency Industry of China Based on SCP Model. Tourism Tribune, 22, 44-49. 
Scientific Research Publishing (SCIRP) is one of the largest Open Access journal publishers. It is currently publishing more than 200 open access, online, peer-reviewed journals covering a wide range of academic disciplines. SCIRP serves the worldwide academic communities and contributes to the progress and application of science with its publication.

Other selected journals from SCIRP are listed as below. Submit your manuscript to us via either submit@scirp.org or Online Submission Portal.
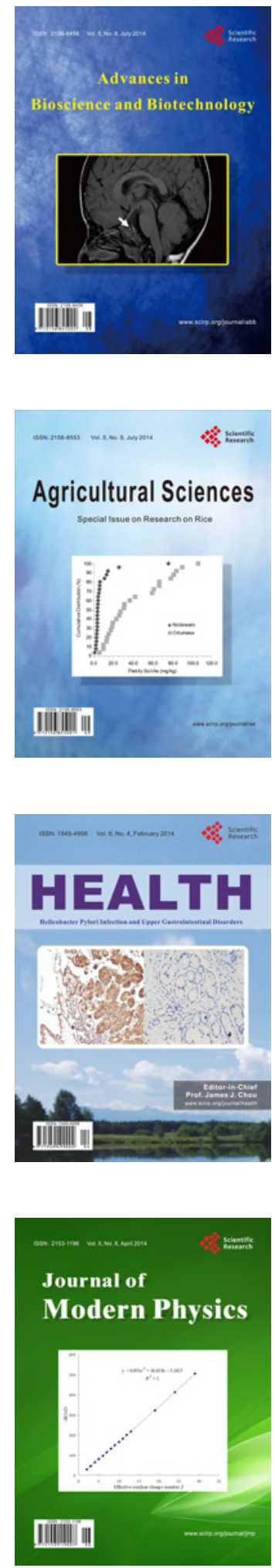
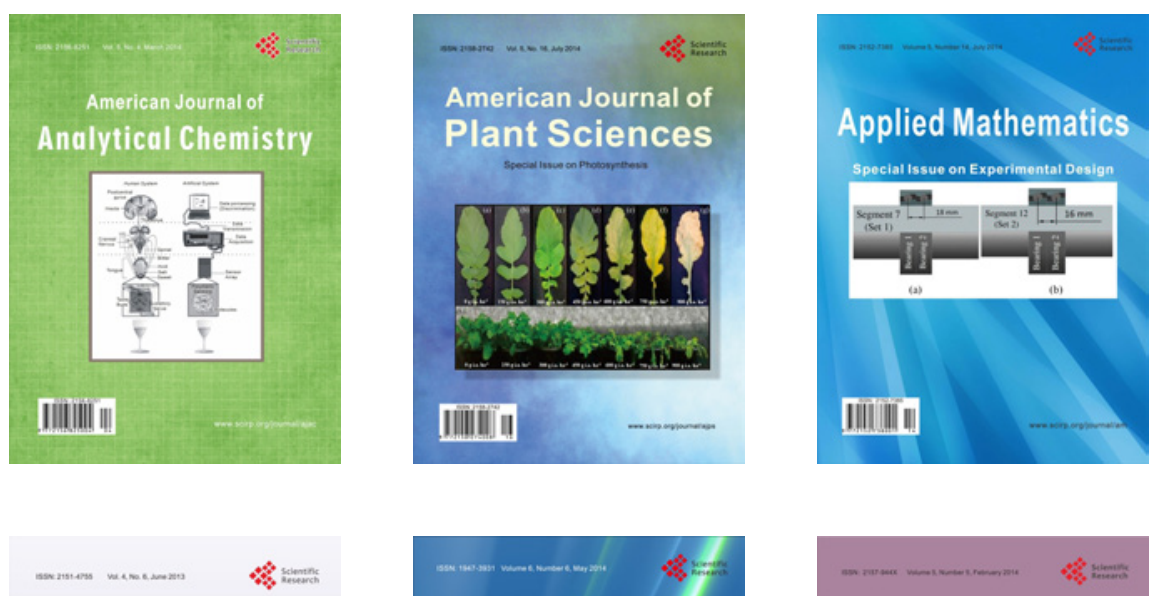

Creative Education
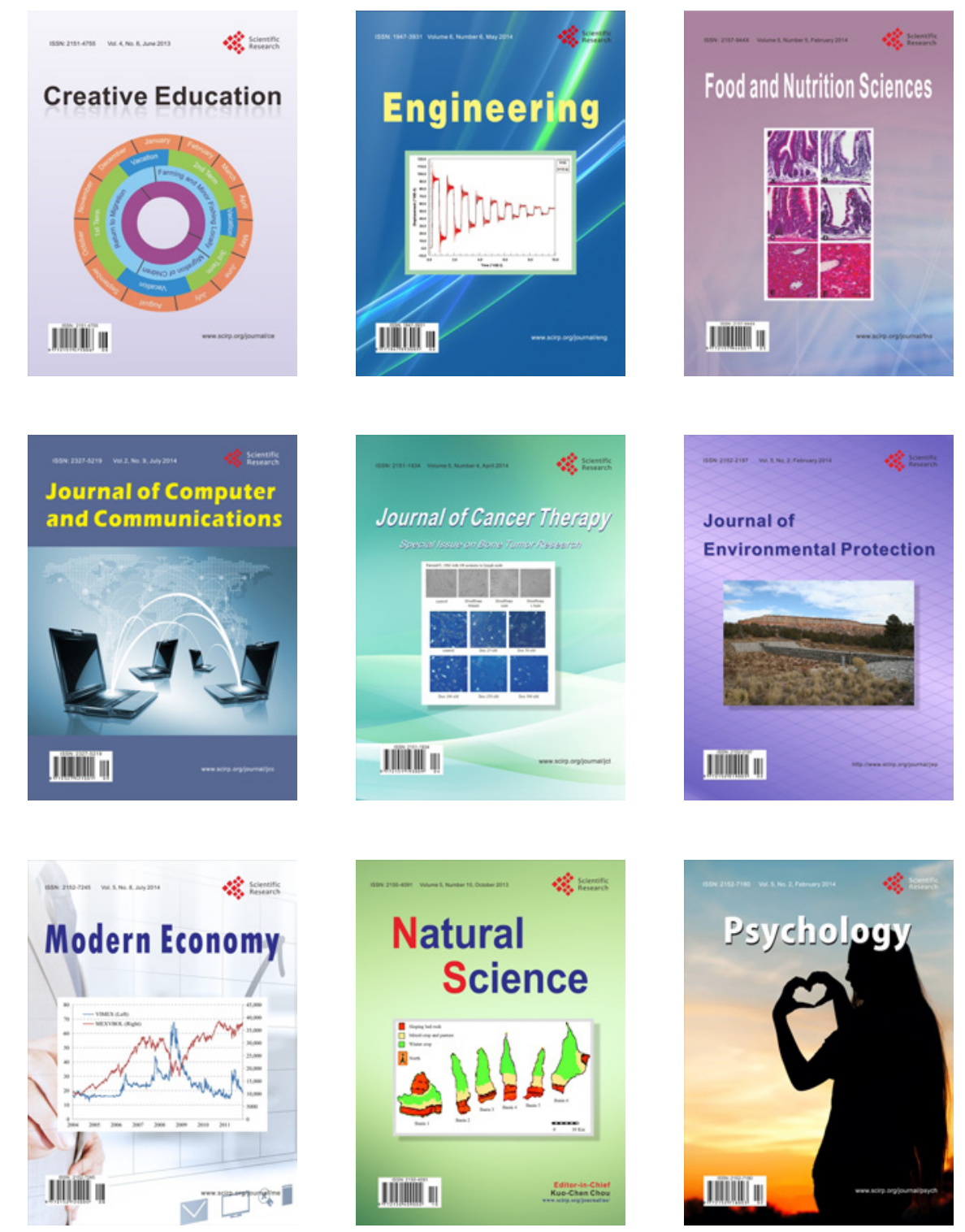